\title{
The World's Wife, de Carol Ann Duffy
}

\author{
Marina Fe y Eva CruZ YÁÑEZ \\ Universidad Nacional Autónoma de México
}

Carol Ann Duffy nació en Glasgow, Escocia, en 1955. En 2009 fue la primera mujer nombrada Poeta Laureada en el Reino Unido. Ha recibido varios premios por sus libros de poesía, entre los que se encuentran: Standing Female Nude, 1985; Selling Manhattan, 1987; The Other Country, 1990; Mean Time, 1993; The World's Wife, 1999; Feminine Gospels, 2002; Rapture, 2005, y The Bees, 2011.

Hemos querido dar a conocer algunos poemas de su colección de The World's Wife, poemas subversivos que cuestionan y desconstruyen los mitos acerca de ciertos "grandes hombres", ya sean personajes históricos o ficcionales, desde el punto de vista de las mujeres. En esta suerte de coro femenino se encuentran, por ejemplo, las esposas de Esopo, Darwin, Fausto, Tiresias, Quasimodo, Lázaro, Shakespeare, Midas y hasta el mismo Diablo. Aparecen también otras que no son esposas, como Medusa, Caperucita Roja y la estatua de Pigmalión.

Como parte de un proyecto de traducción más ambicioso de la obra poética de Duffy, ofrecemos aquí una selección de estos poemas, una breve muestra de su ingenio, su humor, su actitud crítica y a veces satírica, así como del lirismo que recorre, sin duda, toda su obra. 


\section{The World's Wife, de Carol Ann Duffy}

\section{La señora Midas}

Era el final de septiembre. Me había servido una copa de vino, empezaba a relajarme, mientras se cocían las verduras. La cocina se llenó del olor de sí misma, tranquila, su aliento vaporoso empañaba levemente las ventanas. Así que abrí una, luego con los dedos limpié el vidrio de la otra como un arco. Él estaba bajo el peral quebrando una ramita.

Ahora bien, el jardín era largo y la visibilidad mala, así como cuando lo oscuro de la tierra parece beberse la luz del cielo, pero esa ramita en su mano era de oro. Y entonces arrancó una pera de una rama — plantábamos Fondante d'Automney se quedó en la palma de su mano como un foco. Encendido. Pensé para mí, ¿está poniendo luces navideñas en el árbol?

Entró a la casa. Las manijas de las puertas brillaron. Cerró las persianas. Ya saben cómo es la mente; pensé en el Campo de la Tela de Oro y en Miss Macready.

Se sentó en el sillón como un rey en su trono bruñido.

Su mirada era extraña, fiera, engreída. Yo dije, ¿qué está pasando por Dios? Empezó a reír.

Serví la comida. Para empezar, maíz en mazorca.

En segundos empezó a escupir los dientes de los ricos.

Jugueteó con su cuchara, luego con la mía, luego con cuchillos y tenedores. Preguntó por el vino. Se lo serví con mano temblorosa, un vino blanco seco, fragante, de Italia, luego observé cuando tomó la copa de vino, el cáliz dorado, y bebió.

Fue entonces cuando empecé a gritar. Cayó de rodillas. Después de habernos calmado, me terminé el vino yo sola, escuchándolo. Lo obligué a sentarse 


\section{The World's Wife, de Carol Ann Duffy}

\section{Mrs Midas}

It was late September. I'd just poured a glass of wine, begun to unwind, while the vegetables cooked. The kitchen filled with the smell of itself, relaxed, its steamy breath gently blanching the windows. So I opened one, then with my fingers wiped the other's glass like a brow. He was standing under the pear tree snapping a twig.

Now the garden was long and the visibility poor, the way the dark of the ground seems to drink the light of the sky, but that twig in his hand was gold. And then he plucked a pear from a branch — we grew Fondanted'Automne and it sat in his palm like a lightbulb. On.

I thought to myself, Is he putting fairy lights in the tree?

He came into the house. The doorknobs gleamed.

He drew the blinds. You know the mind; I thought of the Field of the Cloth of Gold and of Miss Macready. He sat in that chair like a king on a burnished throne. The look on his face was strange, wild, vain. I said, What in the name of God is going on? He started to laugh.

I served up the meal. For starters, corn on the cob. Within seconds he was spitting out the teeth of the rich. He toyed with his spoon, then mine, then with the knives, the forks. He asked where was the wine. I poured with a shaking hand, a fragrant, bone-dry white from Italy, then watched as he picked up the glass, goblet, golden chalice, drank.

It was then that I started to scream. He sank to his knees. After we'd both calmed down, I finished the wine on my own, hearing him out. I made him sit 
al otro lado del cuarto y a mantener las manos quietas.

Encerré al gato en la bodega. Moví el teléfono.

El excusado no me importaba. No podía creer lo que decía:

cómo había tenido un deseo. Miren, todos tenemos deseos, concedido.

¿Pero a quién se le conceden? A él. ¿Saben algo del oro?

No alimenta a nadie; áureo, suave, no se mancha; no sacia

la sed. Trató de encender un cigarro; yo lo miraba, extasiada, mientras la flama azul bailaba en su tallo luminoso. Al menos, dije, podrás dejar de fumar definitivamente.

Camas separadas. De hecho, puse una silla contra mi puerta, casi petrificada. Él estaba abajo, convirtiendo el cuarto de visitas en la tumba de Tutankamon. Verán, éramos apasionados entonces, en esos días felices; nos desenvolvíamos el uno al otro, rápido, como regalos, comida rápida. Pero ahora temía su abrazo de miel, el beso que haría de mis labios una obra de arte.

¿Y quién, llegado el momento, puede vivir con un corazón de oro? Esa noche, soñé que tenía un hijo suyo, con perfectas piernas de oro, su lengüita como un broche precioso, sus ojos de ámbar conteniendo sus pupilas como moscas. Mi leche soñada me quemaba los pechos. Me despertó el sol radiante.

Entonces tuvo que irse. Teníamos un remolque en el bosque, en un aislado claro de hierba. Lo llevé en el coche protegidos por la oscuridad. Iba sentado atrás.

Y después regresé a casa, la mujer que se casó con el tonto que deseó tener oro. Al principio lo visitaba, de vez en cuando, estacionando el coche bastante lejos, para luego caminar.

Podías saber que te ibas acercando. Truchas doradas en el pasto. Un día, una liebre colgada de un alerce, un hermoso limón equivocado. Y luego sus pisadas, luminosas cerca del camino del río. Estaba flaco, delirante; oía, según él, la música de Pan desde el bosque. Miren. Ésa fue la gota que derramó el vaso.

Lo que me enoja ahora no es la idiotez o la avaricia sino que no haya pensado en mí. Egoísmo puro. Vendí el contenido de la casa y me vine acá. 
on the other side of the room and keep his hands to himself. I locked the cat in the cellar. I moved the phone.

The toilet I didn't mind. I couldn't believe my ears:

how he'd had a wish. Look, we all have wishes; granted.

But who has wishes granted? Him. Do you know about gold?

It feeds no one; aurum, soft, untarnishable; slakes

no thirst. He tried to light a cigarette; I gazed, entranced,

as the blue flame played on its luteous stem. At least,

I said, you'll be able to give up smoking for good.

Separate beds. In fact, I put a chair against my door, near petrified. He was below, turning the spare room into the tomb of Tutankhamun. You see, we were passionate then, in those halcyon days; unwrapping each other, rapidly, like presents, fast food. But now I feared his honeyed embrace, the kiss that would turn my lips to a work of art.

And who, when it comes to the crunch, can live with a heart of gold? That night, I dreamt I bore his child, its perfect ore limbs, its little tongue like a precious latch, its amber eyes holding their pupils like flies. My dream milk burned in my breasts. I woke to the streaming sun.

So he had to move out. We'd a caravan in the wilds, in a glade of its own. I drove him up under cover of dark. He sat in the back.

And then I came home, the woman who married the fool who wished for gold. At first, I visited, odd times, parking the car a good way off, then walking.

You knew you were getting close. Golden trout on the grass. One day, a hare hung from a larch, a beautiful lemon mistake. And then his footprints, glistening next to the river's path. He was thin, delirious; hearing, he said, the music of Pan from the woods. Listen. That was the last straw.

What gets me now is not the idiocy or greed but lack of thought for me. Pure selfishness. I sold the contents of the house and came down here. 
Pienso en él a ciertas horas, con la luz de la mañana, al atardecer, y una vez un platón con manzanas casi me mata de susto. Lo que más extraño, aún ahora, son sus manos tibias, su toque, sobre mi piel.

Trad. Marina Fe

\title{
La señora Darwin
}

Abril 7, 1852

Fuimos al zoológico.

Le dije:

Hay algo en ese chimpancé de ahí que me hace pensar En ti.

\author{
Trad. Marina Fe
}

\section{Anne Hathaway}

"Ítem: que dejo a mi esposa mi segunda mejor cama". (del testamento de Shakespeare)

La cama donde nos amamos era un mundo giratorio de bosques, castillos, antorchas, riscos, mares, donde él buceaba en busca de perlas. Las palabras de mi amado eran estrellas fugaces que caían a tierra como besos en estos labios; mi cuerpo a veces suave rima para el suyo, otras eco, asonancia; su caricia un verbo bailando en el centro de un sustantivo.

Ciertas noches soñaba que él me había escrito, la cama una página bajo sus manos de escritor. Romance y drama interpretados por el tacto, el olfato, el gusto. En la otra cama, la mejor, nuestros invitados dormitaban, babeando su prosa. Mi amor vivo y risueño lo abrazo en el ataúd de mi cabeza viuda como él me abrazaba en esa segunda mejor cama. 
I think of him in certain lights, dawn, late afternoon, and once a bowl of apples stopped me dead. I miss most, even now, his hands, his warm hands on my skin, his touch.

\section{Mrs Darwin}

7 April 1852.

Went to the Zoo.

I said to Him -

Something about that Chimpanzee over there reminds me of you.

\section{Anne Hathaway}

'Item I gyve unto my wief my second best bed...'

(from Shakespeare's will)

The bed we loved in was a spinning world of forests, castles, torchlight, cliff-tops, seas where he would dive for pearls. My lover's words were shooting stars which fell to earth as kisses on these lips; my body now a softer rhyme to his, now echo, assonance; his touch a verb dancing in the centre of a noun. Some nights I dreamed he'd written me, the bed a page beneath his writer's hands. Romance and drama played by touch, by scent, by taste. In the other bed, the best, our guests dozed on, dribbling their prose. My living laughing love I hold him in the casket of my widow's head as he held me upon that next best bed. 


\section{Medusa}

Una sospecha, una duda, un recelo creció en mi mente, y mis cabellos se volvieron serpientes repugnantes, como si mis pensamientos

sisearan y escupieran en mi cabeza.

Mi aliento de novia se volvió acre, fétido

en los sacos grises de mis pulmones.

Ahora tengo boca y lengua inmundas y colmillos amarillos.

Mis lágrimas son balas en mis ojos.

¿Te aterra?

\section{Atérrate}

Es a ti a quien amo, hombre perfecto, Dios Griego, mío nada más; pero sé que te irás, me traicionarás, te alejarás del hogar.

Mucho mejor para mí si fueras de piedra.

Miré de pronto a una abeja zumbante, y una piedrecilla gris pardo cayó al suelo.

Miré de pronto a un pájaro cantando, $y$ un puño de grava polvorienta se esparció en la tierra.

Miré a un gato anaranjado, $\mathrm{y}$ un ladrillo quebró un tazón de leche.

Miré a un cerdo que resoplaba, y un peñasco se revolcó en un montón de estiércol.

Miré directamente al espejo.

El amor malogrado me mostró una Gorgona.

Miré fijamente a un dragón.

Una montaña escupió fuego por la boca. 


\section{Medusa}

A suspicion, a doubt, a jealousy

grew in my mind,

which turned the hairs on my head to filthy snakes,

as though my thoughts

hissed and spat on my scalp.

My bride's breath soured, stank

in the grey bags of my lungs.

I'm fouled mouthed now, foul tongued,

yellow fanged.

There are bullet tears in my eyes.

Are you terrified?

Be terrified.

It's you I love,

perfect man, Greek God, my own;

but I know you'll go, betray me, stray

from home.

So better by far for me if you were stone.

I glanced at a buzzing bee,

a dull grey pebble fell

to the ground.

I glanced at a singing bird,

a handful of dusty gravel

spattered down.

I looked at a ginger cat,

ahousebrick

shattered a bowl of milk

I looked at a snuffling pig,

a boulder rolled

in a heap of shit.

I stared in the mirror.

Love gone bad

showed me a Gorgon.

I stared at a dragon.

Fire spewed

from the mouth of a mountain. 
$\mathrm{Y}$ aquí vienes

con un escudo por corazón

$\mathrm{y}$ una espada por lengua

$\mathrm{y}$ tus mujeres, tus mujeres.

¿Acaso no era yo hermosa?

¿No era fragante y joven?

Mírame ahora.

Trad. Eva Cruz Yáñez

\section{La señora Lázaro}

Había guardado luto. Había llorado día y noche por mi pérdida, arrancado de mi pecho el vestido con el que me casé, aullado, gritado, arañado las piedras del sepulcro hasta sangrar mis manos, repetido su nombre en arcadas una y otra vez, muerto, muerto.

Había regresado a casa. Destripado el lugar. Dormido en un catre individual, viuda, un guante vacío, fémur blanquecino en el polvo, una mitad. Había metido trajes oscuros en bolsas negras, arrastrado los pies en los zapatos de un muerto, anudado una corbata alrededor de mi cuello desnudo,

monja enjuta en el espejo, toquetéandose. Aprendí las Estaciones del Duelo, viendo el icono de mi rostro en cada lúgubre marco; pero durante todos esos meses él se iba alejando de mí, encogiéndose al reducido tamaño de una foto, se iba yendo,

yendo. Hasta que su nombre dejó de ser un conjuro infalible para ver su rostro. El último cabello de su cabeza salió flotando de un libro. Su olor se fue de la casa. Se leyó el testamento. Vean, se iba desvaneciendo hasta ser el insignificante cero cercado por el oro de mi sortija.

Entonces desapareció. Luego se volvió leyenda, lenguaje; paseé del brazo del maestro de escuela — el impacto de sentir la fuerza de un hombre bajo la manga de su saco- 
An here you come

with a shield for a heart

and a sword for a tongue

and your girls, your girls.

Wasn't I beautiful?

Wasn't I fragrant and young?

Look at me now.

\section{Mrs Lazarus}

I had grieved. I had wept for a night and a day over my loss, ripped the cloth I was married in from my breasts, howled, shrieked, clawed at the burial stones till my hands bled, retched his name over and over again, dead, dead.

Gone home. Gutted the place. Slept in a single cot, widow, one empty glove, white femur in the dust, half. Stuffed dark suits into black bags, shuffled in a dead man's shoes, noosed the double knot of a tie round my bare neck,

gaunt nun in the mirror, touching herself. I learnt the Stations of Bereavement, the icon of my face in each bleak frame; but all those months he was going away from me, dwindling to the shrunk size of a snapshot, going,

going. Till his name was no longer a certain spell for his face. The last hair on his head floated out from a book. His scent went from the house. The will was read. See, he was vanishing to the small zero held by the gold of my ring.

Then he was gone. Then he was legend, language; my arm on the arm of the schoolteacher - the shock of a man's strength under the sleeve of his coat - 
a lo largo de los setos. Pero fui fiel

el tiempo necesario. Hasta que se volvió recuerdo.

De modo que esa tarde me detuve en el campo envuelta en un chal de aire suave, curada, y pude contemplar la orilla de la luna acudir al cielo y a una liebre saltar de un cerco; luego reparé en los hombres del pueblo que corrían hacia mí, gritando,

las mujeres y niños detrás, los perros ladrando, y entonces lo supe. Lo supe por la taimada luz en el rostro del herrero, los ojos estridentes de la mesera del bar, las manos inesperadas llevándome entre el punzante olor acre de la multitud que se abría a mi paso.

Estaba vivo. Pude ver el horror en su rostro. Oí el canto enloquecido de su madre. Aspiré su hedor; mi esposo en su mortaja putrefacta, húmeda y descompuesta por la lenta corrosión de la tumba, croando su nombre cornudo, desheredado, fuera de su tiempo.

Trad. Eva Cruz Yáñez

\section{La novia de Pigmalión}

Fría, estaba, como nieve, como marfil.

Pensé No me va a tocar, pero lo hizo.

Besó mis labios de piedra fría Me quedé quieta como si hubiera muerto.

El se detuvo pasó sus dedos sobre mis ojos de mármol.

Habló

torpes palabras dulces, qué haría y cómo.

Sus palabras fueron terribles. 
along the hedgerows. But I was faithful

for as long as it took. Until he was a memory.

So I could stand that evening in the field in a shawl of fine air, healed, able to watch the edge of the moon occur to the sky and a hare thump from a hedge; then notice the village men running towards me, shouting,

behind them the women and children, barking dogs, and I knew. I knew by the sly light on the blacksmith's face, the shrill eyes of the barmaid, the sudden hands bearing me into the hot tang of the crowd parting before me.

He lived. I saw the horror on his face.

I heard his mother's crazy song. I breathed his stench; my bridegroom in his rotting shroud, moist and dishevelled from the grave's slack chew, croaking his cuckold name, disinherited, out of his time.

\section{Pygmalion's Bride}

Cold, I was, like snow, like ivory.

I thought, He will not touch me, but he did.

He kissed my stone-cool lips.

I lay still

as though I'd died.

He stayed.

He thumbed my marbled eyes.

He spoke -

blunt endearments, what he'd do and how.

His words were terrible. 
Mis orejas eran escultura, de piedra sorda, conchas.

Oía el mar.

Ahogaba su voz

Lo oía gritar.

Me trajo regalos, piedrecillas pulidas, campanitas.

No parpadeé, estaba muda.

Me trajo perlas y collares y anillos.

Los llamaba cosas de chicas

Recorría sus manos pegajosas por mis piernas, No me moví.

Jugué a la estatua, calladita.

Dejé que sus dedos se hundieran en mi carne, pellizcó, apretó.

No me salían moretones.

Buscó marcas, corazones morados, estrellas de tinta, señales de tizne.

Sus uñas eran garras.

Yo no mostraba arañazos, raspones, cicatrices.

Me recostó en almohadas, parloteó toda la noche.

Mi corazón era de hielo, de cristal.

$\mathrm{Su}$ voz era de grava, ronca.

Hablaba blanco y negro.

Así que cambié de plan, me entibié, como cera de velas, le devolví los besos, fui suave, dúctil, empecé a gemir, me calenté, me puse salvaje, me arqueé, me enrosqué, me retorcí, le supliqué por un hijo, y en el clímax grité como locatoda una actuación. 
My ears were sculpture,

stone-deaf, shells.

I heard the sea.

I drowned him out.

I heard him shout.

He brought me presents, polished pebbles,

little bells.

I didn't blink,

was dumb.

He brought me pearls and necklaces and rings.

$\mathrm{He}$ called them girly things.

He ran his clammy hands along my limbs.

I didn't shrink,

played statue, schtum.

He let his fingers sink into my flesh,

he squeezed, he pressed.

I would not bruise.

He looked for marks,

for purple hearts,

for inky stars, for smudgy clues.

His nail were claws.

I showed no scratch, no scrape, no scar.

He propped me up on pillows, jawed all night.

My heart was ice, was glass.

His voice was gravel, hoarse.

He talked white black.

So I changed tack,

grew warm, like candle wax,

kissed back,

was soft, was pliable,

began to moan,

got hot, got wild,

arched, coiled, writhed,

begged for his child,

and at the climax

screamed my head off -

all an act. 
Y no lo he visto desde entonces.

Así de simple.

$$
\text { Trad. Marina Fe }
$$

\section{Penélope}

Al principio miraba a lo largo del camino

esperando verlo llegar sin prisa a casa

entre los olivos,

un silbido para el perro

que lo lloraba con la tibia cabeza sobre mis rodillas.

Seis meses de esto

y luego descubrí que días enteros habían pasado

sin que me diera cuenta.

Preparé tela y tijeras, aguja, hilo

pensando en entretenerme,

pero encontré la labor para toda mi vida en lugar de eso.

Cosí una niña

bajo una sola estrella — punto de cruz, seda plateada-

corriendo tras el rebote de la pelota de su infancia.

Escogí entre tres verdes para el pasto;

un rosa ahumado, un gris de sombra

para mostrar a una libélula tragándose una abeja.

Ensarté el café marrón para un árbol,

con mi dedal como una bellota

empujando a través de la tierra oscura.

Bajo la sombra

envolví a una muchacha en un profundo abrazo

con el chico del heroísmo

y me perdí por completo

en un bordado loco de amor, deseo, pérdida, lecciones aprendidas;

luego lo vi irse navegando

hacia las puntadas sueltas y doradas del sol.

Y cuando los otros llegaron a ocupar su lugar,

a perturbar mi paz,

jugué para ganar tiempo.

Ponía cara de viuda, con la cabeza gacha, 
And I haven't seen him since.

Simple as that.

\section{Penelope}

At first, I looked along the road

hoping to see him saunter home

among the olive trees,

a whistle for the dog

who mourned him with his warm head on my knees.

Six months of this

and then I noticed that whole days had passed

without my noticing.

I sorted cloth and scissors, needle, thread,

thinking to amuse myself,

but found a lifetime's industry instead.

I sewed a girl

under a single star — cross-stitch, silver silk -

running after childhood's bouncing ball.

I chose between three greens for the grass;

a smoky pink, a shadow's grey

to show a snapdragon gargling a bee.

I threaded walnut brown for a tree,

my thimble like an acorn

pushing up through umber soil.

Beneath the shade

I wrapped a maiden in a deep embrace

with heroism's boy

and lost myself completely

in a wild embroidery of love, lust, lessons learnt;

then watched him sail away

into the loose gold stitching of the sun.

And when the others came to take his place,

disturb my peace,

I played for time.

I wore a widow's face, kept my head down, 
hacía mi labor durante el día, la deshacía en la noche.

Sabía a qué hora del anochecer la luna

empezaría a deshilacharse,

yo la hilvanaba.

Hilos grises y cafés

perseguían a los peces saltarines de mi aguja

para formar un río que nunca llegaría al mar.

Era una trampa. Estaba escogiendo

la sonrisa de una mujer en el centro

de este mundo, contenida en sí misma, absorta, satisfecha,

pero que sobre todo no esperaba a nadie,

cuando escuché ya demasiado tarde pasos conocidos afuera de la puerta.

Lamí el hilo escarlata

y lo dirigí con precisión al centro del ojo de la aguja una vez más.

Trad. Marina Fe 
did my work by day, at night unpicked it.

I knew which hour of the dark the moon

would start to fray,

I stitched it.

Grey threads and brown

pursued my needle's leaping fish

to form a river that would never reach the sea.

I tricked it. I was picking out

the smile of a woman at the centre

of this world, self-contained, absorbed, content,

most certainly not waiting,

when I heard a far-too-late familiar tread outside the door.

I licked my scarlet thread

and aimed it surely at the middle of the needle's eye once more. 